\title{
Facial Expression Recognition By Using Fisherface Methode With Backpropagation Neural Network
}

\author{
Zaenal Abidin dan Agus Harjoko
}

\begin{abstract}
In daily lives, especially in interpersonal communication, face often used for expression. Facial expressions give information about the emotional state of the person. A facial expression is one of the behavioral characteristics. The components of a basic facial expression analysis system are face detection, face data extraction, and facial expression recognition. Fisherface method with backpropagation artificial neural network approach can be used for facial expression recognition. This method consists of two-stage process, namely PCA and LDA. PCA is used to reduce the dimension, while the LDA is used for features extraction of facial expressions. The system was tested with 2 databases namely JAFFE database and MUG database. The system correctly classified the expression with accuracy of $86.85 \%$, and false positive 25 for image type I of JAFFE, for image type II of JAFFE $89.20 \%$ and false positive 15, for type III of JAFFE 87.79\%, and false positive for 16. The image of $M U G$ are $98.09 \%$, and false positive 5 .
\end{abstract}

Keywords - facial expression, fisherface method, PCA, LDA, backpropagation neural network.

\section{PENDAHULUAN}

$\mathrm{D}^{\mathrm{i}}$ dalam kehidupan sehari hari, khususnya dalam komunikasi interpersonal, wajah sering digunakan untuk berekspresi. Melalui ekspresi wajah, maka dapat dipahami emosi yang sedang bergejolak pada diri individu. Ekspresi atau mimik sendiri sebenarnya adalah salah satu bentuk komunikasi nonverbal yang merupakan hasil dari satu atau lebih gerakan atau posisi otot pada wajah serta dapat menyampaikan keadaan emosi dari seseorang kepada orang yang mengamatinya.

Z. Abidin, Universitas Negeri Semarang, e-mail zaenalabidin@staff.unnes.ac.id

A. Harjoko, Elektronika dan Instrumentasi, Jurusan Ilmu Komputer dan Elektronika, Fakultas MIPA, Universitas Gadjah Mada, Yogyakarta, e-mail : aharjoko@ugm.ac.id
Ekspresi wajah mengungkapkan pikiran yang sedang melintas pada diri seseorang. Sebagai contoh, sebuah senyum mengungkap keramahtamahan dan kasih-sayang; mengangkat alis mata menunjukkan ekspresi heran; mengernyitkan dahi menunjukkan ketakutan dan kegelisahan. Semua emosi dan berbagai macam tingkah manusia diekspresikan dalam emosi yang berbeda yang tergambar di wajah.

Seorang psikolog bernama Mehrabian dalam penelitiannya menyatakan bahwa ekspresi wajah menyumbang sebesar $55 \%$ dalam penyampaian pesan, sementara bahasa dan suara masing-masing menyumbang $7 \%$ dan 38\%. Paul Ekman, seorang psikolog Amerika juga mendefinisikan enam kategori klasifikasi emosi yaitu senang, sedih, terkejut, marah, takut dan jijik. Kebanyakan sistem pengenal ekspresi wajah, mengklasifikasikan emosi ke dalam enam kategori universal tersebut, [4].

Dewasa ini teknologi menggunakan biometrika telah banyak sekali diaplikasikan. Teknologi biometrika diterapkan dengan menggunakan karakteristik pembeda (distinguishing traits). Secara umum karakteristik pembeda itu sendiri dibedakan menjadi 2, yaitu karakteristik fisiologis atau fisik, dan karakteristik perilaku. Ekspresi wajah merupakan salah satu karakteristik perilaku. Penggunaan sistem teknologi biometrika dengan karakteristik ekspresi wajah memungkinkan untuk mengenali mood atau emosi seseorang.

Analisis ekspresi wajah berhubungan dengan pengenalan secara visual gerakan wajah dan perubahan fitur wajah. Komponen dasar sistem analisis ekspresi wajah adalah deteksi wajah, ekstraksi data wajah, dan pengenalan ekspresi wajah.

Beberapa penelitian yang telah dilakukan dan yang berkaitan dengan ekspresi wajah diantaranya dilakukan oleh Lekshmi dan Sasikumar [5], yang melakukan analisis ekspresi wajah dengan menggunakan metode Gabor Wavelet Transform (GWT) dan DCT. Jaringan Radial Basis Function (RBF) digunakan sebagai classifier. Bashyal dan Venayagamoorthy [1], 
melakukan pengenalan ekspresi wajah dengan menggunakan Gabor wavelet untuk mengekstraksi ciri dan mengkombinasikannya dengan LVQ untuk mengenali tujuh ekspresi wajah. Kulkarni [4], mengklasifikasikan ekspresi wajah secara efektif berdasarkan input parameter wajah menggunakan committee neural network. Deng [3], mengembangkan sebuah penelitian yang membandingkan metode bank tapis gabor lokal dan global dengan pendekatan PCA+LDA sebagai pereduksi dimensi, sedangkan pada tahap klasifikasi digunakan jarak minimum Euclid. Ma dan Khorasani [7], melakukan penelitian dengan menggunakan 2-D discrete cosine transform (DCT) untuk mendeteksi ciri dan jaringan syaraf feedforward dengan satu layer tersembunyi sebagai pengklasifikasi ekspresi wajah.

\section{ANALISIS DAN KEBUTUHAN SISTEM}

Sistem yang dibangun adalah sistem untuk pengenalan ekspresi wajah yang dilakukan dengan mengenali pola dari citra wajah. Ekspresi yang akan dikenali adalah ekspresi netral plus 6 ekspresi dasar wajah yaitu: senang, sedih, marah, terkejut, takut dan jijik. Pengenalan ekspresi wajah didasari pada pengenalan pola dengan pendekatan jaringan syaraf menggunakan algoritma backpropagation. Proses pengenalan ekspresi wajah dilakukan dengan membandingkan citra input dengan citra yang telah dilatih oleh sistem.

Secara garis besar, penelitian ini terdiri dari beberapa tahap yaitu:

1. Proses pengambilan citra digital.

Citra yang digunakan untuk penelitian ini terdiri dari sekumpulan citra untuk pelatihan (training data set) dan sekumpulan citra untuk pengujian (testing data set). Data citra untuk pelatihan dan pengujian diperoleh dari dua sumber database yakni:

a. JAFFE database [6], yang terdiri dari 213 gambar ekspresi wajah dari 10 subyek wanita Jepang. Setiap subyek berpose 3 sampai 4 untuk 6 ekspresi wajah +1 netral. Setiap gambar memiliki format tiff, dengan mode warna grayscale dan memiliki ukuran $256 \times 256$ piksel.

b. MUG database [2], yang digunakan adalah 18 subyek dengan total citra adalah 630 buah citra. Masing-masing subyek berpose untuk 7 ekspresi wajah. Dari database yang ada diambil sebanyak 5 citra per ekspresi. Setiap gambar memiliki format jpg, dengan model warna RGB dan memiliki ukuran $896 \times 896$ piksel.

Rincian pembagian data citra yang akan digunakan untuk pelatihan dan pengujian ditunjukkan dalam Tabel 1.

Tabel 1. Rincian pembagian data citra

\begin{tabular}{|l|c|c|c|}
\hline $\begin{array}{c}\text { Nama } \\
\text { Database }\end{array}$ & $\begin{array}{c}\text { Jumlah } \\
\text { Citra Latih }\end{array}$ & $\begin{array}{c}\text { Jumlah } \\
\text { Citra Uji }\end{array}$ & $\begin{array}{c}\text { Total } \\
\text { Citra }\end{array}$ \\
\hline JAFFE & 140 & 73 & 213 \\
\hline MUG & 504 & 126 & 630 \\
\hline
\end{tabular}

2. Proses pengolahan citra meliputi normalisasi ukuran, histogram equalization, dan masking.

3. Proses membuat data input menggunakan metode fisherface yang akan digunakan pada proses learning pada jaringan syaraf tiruan.

4. Proses pelatihan untuk citra training data set.

Pengenalan citra yang akan dikenali jenis ekspresinya (testing data set) baik citra yang ada di dalam training data set maupun citra yang belum dilakukan pelatihan sebelumnya.

\section{SISTEM PEMROSESAN}

Dalam penelitian ini, untuk membangun sistem pengenalan ekspresi wajah dilakukan dengan dua tahapan proses yaitu proses pelatihan citra training data set dan proses pengenalan citra yang akan dikenali. Gambar 1 menunjukkan fase pelatihan dan fase pengenalan untuk sistem pengenalan ekspresi wajah.

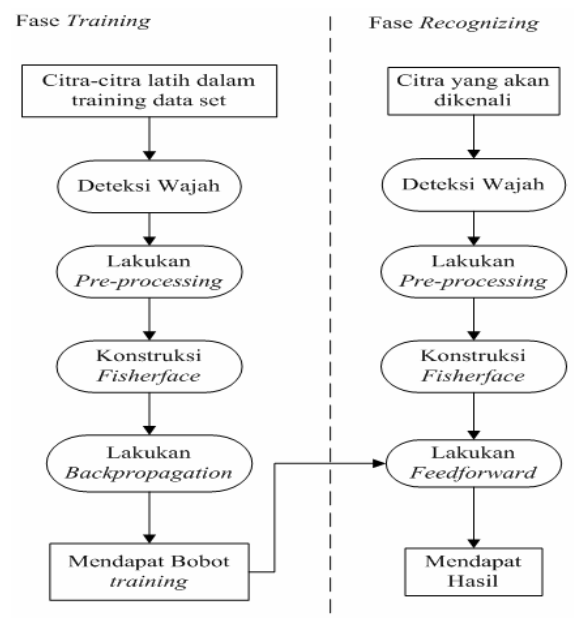

Gambar 1. Sistem pemrosesan pengenalan ekspresi wajah 


\section{III.I DETEKSI WAJAH}

Sistem deteksi wajah dipandang sebagai pengenalan pola di mana inputnya adalah citra masukan dan akan ditentukan output yang berupa label kelas dari citra tersebut. Dalam hal ini terdapat dua label kelas, yaitu wajah dan non-wajah.

Salah satu kunci sukses dalam pengenalan ekspresi wajah adalah deteksi wajah yang akurat, karena gambar wajah yang terdeteksi akan sangat mempengaruhi dalam proses pengenalannya. Langkah pertama pada pengenalan ekspresi wajah secara otomatis adalah mendeteksi keberadaan wajah dari gambar masukan. Dalam penelitian ini digunakan metode integral projection. Integral projection adalah suatu metode yang digunakan untuk mencari daerah atau lokasi dari obyek. Teknik ini dikemukan oleh T. Kanade (dalam Yisu et al, 2009). Ide dasar tentang integral projection pada tingkat keabuan adalah menjumlahkan piksel per baris dan piksel per kolom. Misalkan sebuah gambar berukuran $\mathrm{m} \times \mathrm{n}$, dan tingkat keabuan setiap pikselnya adalah $I(x, y)$, maka fungsi vertical projection dapat dirumuskan seperti persamaan (1) sebagai berikut.

$$
S_{y}(x)=\sum_{y=1}^{x} I(x, y)
$$

Sedangkan untuk persamaan fungsi horizontal projection ditunjukkan pada persamaan (2).

$$
S_{x}(y)=\sum_{x=1}^{y} I(x, y)
$$

Ilustrasi sistem deteksi wajah dengan menggunakan metode integral projection ditunjukkan oleh Gambar 2.
Dari grafik integral projection yang telah diperoleh, selanjutnya ditentukan titik-titik minimum lokal untuk menentukan batas wajah.

\section{III.II PRE-PROCESSING}

Tahap pre-processing untuk proses pelatihan dilakukan dengan otomatisasi melalui deteksi wajah, yaitu dengan mendeteksi daerah wajah dan melakukan normalisasi ukuran. Citra dari database JAFFE akan digunakan 3 ukuran dalam proses normalisasi ukuran yaitu untuk tipe I $33 \times 29$ piksel, untuk tipe II $65 \times 57$ piksel, dan untuk tipe III $130 \times 114$ piksel. Selanjutnya dilakukan histogram equalization untuk melakukan perluasan kontras citra, serta masking untuk menutup bagian sudut-sudut citra sehingga mengurangi variasi yang timbul pada bagianbagian tersebut.

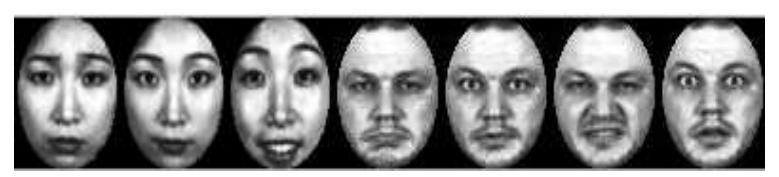

Gambar 3. Contoh data wajah yang telah mengalami pre-processing

\section{III.III KONTRUKSI FISHERFACE}

\section{Setelah (1)}

Setelah melalui tahap pre-processing, kemudian pembuatan set fisherface dari suatu set citra training dengan metode fisherface, yaitu dengan menggunakan perhitungan PCA dan LDA. Sebelumnya matriks representasi citra wajah diubah menjadi vektor kolom, sehingga tiap citra akan direpresentasikan menjadi vektor kolom. Jika citra memiliki ukuran $M \times N$, maka vektor kolom yang terbentuk berukziran $M N \times 1$. Berikut ini adalah langkah pembuatan set fisherface.

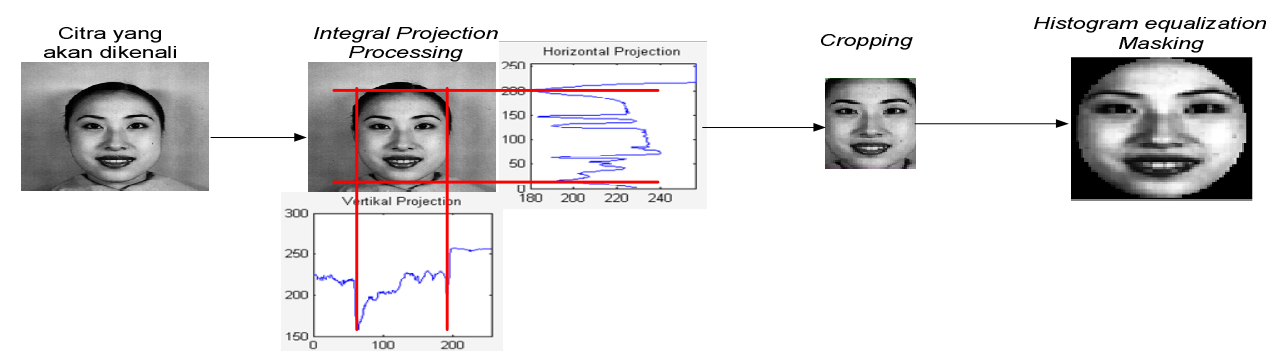

Gambar 2. Ilustrasi sistem deteksi wajah menggunakan metode integral projection 
1. Perhitungan PCA

Adapun langkah perhitungan PCA sebagai berikut.

a. Mengambil satu set gambar yang akan dilatih, kemudian mentransformasikan setiap gambar tersebut menjadi vektor kolom, sehingga akan didapat satu matriks yang tiap kolomnya mewakili gambar yang berbeda, face space. Matriks tersebut berukuran MN $\times p$, dimana $p$ adalah jumlah keseluruhan citra latih.

b. Mencari mean face yaitu nilai rata-rata dari seluruh gambar wajah dari training data set, dan mengurangi seluruh gambar pada training set terhadap mean face untuk mencari deviasinya.

c. Menghitung matriks kovarians. Matriks kovarians berdimensi $m \times m$.

d. Menghitung eigenvalue dan eigenvector dari matriks kovarians yang telah diperoleh. Eigenvalue dan eigenvector yang bersesuaian diurutkan secara descending .

e. Menghitung matriks proyeksi PCA yaitu dengan mengalikan nilai deviasi dengan eigenvector.

f. Mengambil P-K komponen dari matriks proyeksi PCA yang diperlukan untuk mengkonstruksi fisherface, dimana $\mathrm{P}$ adalah total citra latih dan $\mathrm{K}$ adalah banyaknya kelas.

\section{Perhitungan LDA}

Proses perhitungan LDA dapat dilakukan dengan langkah sebagai berikut.

a. Mentransformasikan training set ke dalam vektor kolom (face space).

b. Mencari mean face dari face space, dan nilai wajah rata-rata masing-masing kelas (class mean face)

c. Melakukan perhitungan matriks sebaran dalam kelas (within class scatter matrix, $S_{B}$ ) dan matriks sebaran antar kelas (between class scatter matrix, $S_{W}$ ).

d. Memproyeksikan matriks sebaran $\left(S_{B}\right.$ dan $S_{W}$ ) ke dalam matriks proyeksi PCA.

e. Menghitung eigenvalue dan eigenvector dari matriks sebaran yang diperoleh.

f. Menghitung matriks proyeksi fisher dengan mengurutkan eigenvector berdasarkan besarnya eigenvalue masingmasing eigenvector dan mengambil komponen eigenvector yang memiliki nilai eigen tidak nol. Untuk K kelas, akan selalu didapat $\mathrm{K}-1$ eigenvector yang memiliki eigenvalue tidak nol.

\section{III.IV PEMBELAJARAN BACKPROPAGATION}

Tujuan pembelajaran jaringan adalah keseimbangan antara kemampuan memorisasi dan generalisasi. Hasil pembelajaran jaringan syaraf tiruan diharapkan tidak hanya baik dalam memprediksi pada citra masukan training data set, akan tetapi juga baik dalam memprediksi citra yang akan dikenali di testing data set.

Arsitektur jaringan yang digunakan untuk penelitian terdiri dari 3 layer, yaitu 1 input layer, 1 hidden layer, dan 1 output layer. Jumlah neuron input layer adalah 6 ditambah dengan 1 bias, sesuai dengan keluaran dari konstruksi fisherface yang terdiri dari 6 nilai eigenvector yang signifikan. Layer kedua yaitu hidden layer yang jumlahnya divariasi yaitu 12 , 60, dan 120 ditambah 1 bias. Jumlah neuron pada output layer adalah 7 buah neuron yaitu sesuai dengan target yang diteliti yang terdiri dari 6 ekspresi dasar wajah +1 netral. Fungsi aktivasi yang digunakan untuk layer tersembunyi adalah fungsi sigmoid bipolar, sedangkan pada layer output digunakan fungsi sigmoid biner karena nilai keluaran yang diharapkan berada pada range $[0,1]$. Output dari masing-masing neuron dikonversi ke nilai biner dalam bentuk 0 atau 1 . Sebuah output lebih dari atau sama dengan 0,6 dikonversi menjadi 1 , sedangkan output kurang dari 0,6 dikonversi menjadi 0 . Nilai output 1 mengindikasikan ekspresi tertentu ada dan nilai output 0 mengindikasikan bahwa ekspresi tertentu tidak ada. Nilai learning rate divariasi 0,25 dan 0,5, target error yang digunakan adalah 0,0001 dan maksimum epoh yang diinginkan adalah 1000 . Konfigurasi output NN dan interpretasi ditunjukkan pada Tabel 2.

\begin{tabular}{|c|c|c|c|c|c|c|c|}
\hline $\begin{array}{c}\text { Node } \\
1 \\
\text { Jijik }\end{array}$ & $\begin{array}{c}\text { Node } \\
2 \\
\text { Tahut }\end{array}$ & $\begin{array}{c}\text { Node } 3 \\
\text { Tetkejut }\end{array}$ & $\begin{array}{c}\text { Node } \\
4 \\
\text { Marah }\end{array}$ & $\begin{array}{c}\text { Node } \\
5 \\
\text { Sedih }\end{array}$ & $\begin{array}{l}\text { Node } 6 \\
\text { Senang }\end{array}$ & $\begin{array}{c}\text { Node } \\
7 \\
\text { Netral }\end{array}$ & $\begin{array}{l}\text { NN } \\
\text { Output }\end{array}$ \\
\hline 1 & 0 & 0 & 0 & 0 & 0 & 0 & Jijik \\
\hline 0 & 1 & 0 & 0 & 0 & 0 & 0 & Takut \\
\hline 0 & 0 & 1 & 0 & 0 & 0 & 0 & Tetkeint \\
\hline 0 & 0 & 0 & 1 & 0 & 0 & 0 & Marah \\
\hline 0 & 0 & 0 & 0 & 1 & 0 & 0 & Sedih \\
\hline 0 & 0 & 0 & 0 & 0 & 1 & 0 & Senang \\
\hline 0 & 0 & 0 & 0 & 0 & 0 & 1 & Netral \\
\hline
\end{tabular}

Tabel 2. Konfigurasi output $N N$ dan interpretasi 
Langkah pembelajaran pada jaringan backpropagation adalah sebagai berikut.

1. Inisialisasi parameter dari jaringan, meliputi:

a) Mengeset jumlah neuron hidden layer.

b) Mengeset learning rate, $\alpha(0 \leq \alpha \leq 1)$.

c) Mengeset target error.

d) Mengeset maksimum epoh.

2. Inisialisasi bobot (bobot dipilih secara random dengan nilai yang kecil dengan range antara - 1 dan 1).

Setelah dilakukan inisialisasi, berikutnya adalah tahapan feedforwad yaitu menjumlahkan sinyal-sinyal input terbobot pada hidden layer dan output layer. Sinyal dari input layer ke hidden layer diaktivasi dengan fungsi sigmoid bipolar dan sinyal dari hidden layer ke output layer diaktivasi dengan fungsi sigmoid biner. Tahap berikutnya adalah tahap backpropagation yang dimulai dengan menghitung informasi error. Informasi error diperoleh dari selisih antara nilai target yang telah ditentukan dengan nilai keluaran dari output layer. Informasi error tersebut digunakan untuk mengoreksi bobot pada unit output dan hidden. Koreksi bias dilakukan pula pada unit output dan unit hidden. Tiap-tiap unit output dan unit hidden memperbaiki bobot dan biasnya langkah tersebut di atas dikerjakan berulang-ulang selama kurang dari maksimum epoh atau MSE kurang dari target error. Bobot akhir selanjutnya disimpan untuk dimanfaatkan pada proses pengenalan.

\section{III.V PENGENALAN EKSPRESI WAJAH}

Langkah pengenalan ekspresi wajah, terhadap citra yang akan dikenali adalah sebagai berikut.

1. Memasukkan citra yang akan dikenali ke sistem pengenalan ekspresi.

2. Dilakukan deteksi wajah pada citra yang akan dikenali oleh sistem.

3. Proses pengenalan ekspresi wajah.

Data wajah yang berhasil dideteksi, dicropping, kemudian dilakukan normalisasi ukuran, histogram equalization dan masking, selanjutnya dilakukan konstruksi fisherface yang hasilnya dapat diinputkan ke jaringan syaraf tiruan, dalam hal ini proses yang adalah proses feedforward.
Hasil keluaran jaringan syaraf ini dibandingkan dengan target, kemudian ditampilkan hasilnya.

\section{HASIL DAN PEMBAHASAN}

\section{IV.I PENGUKuRAN EVAluasi UnJUK KeRJA SISTEM}

Pengukuran evaluasi unjuk kerja dari sistem pengenalan ekspresi wajah, pada digunakan dua parameter, yaitu recognition rate dan false positive rate. Recognition rate adalah perbandingan antara jumlah wajah yang berhasil dikenali ekspresinya dengan benar dengan jumlah seluruh wajah yang ada. Sedangkan false positive rate adalah banyaknya ekspresi wajah yang terklasifikasi tidak sesuai dengan ekspresi yang seharusnya.

\section{IV.II PEMBAHASAN Hasil DETEKSI WAJAH}

Penelitian ini menggunakan otomatisasi deteksi wajah terhadap citra query yang akan dikenali jenis ekspresinya. Metode yang digunakan untuk deteksi wajah adalah metode integral projection. Metode ini menjumlahkan tiap-tiap piksel perbaris dan perkolom. Jadi setiap piksel dalam satu baris dijumlahkan sepanjang lebar dari citra, sebanyak tinggi citra dan selanjutnya disebut horizontal integral projection. Setiap piksel dalam satu kolom juga dijumlahkan sepanjang tinggi citra, sebanyak lebar citra, dan selanjutnya disebut dengan vertikal integral projection.

Wajah yang terdeteksi selanjutnya dicropping berdasarkan batas nilai yang telah diperoleh dari proses integral projection, yang selanjutnya dilakukan histogram equalization untuk mengurangi pengaruh variasi pencahayaan, kemudian dilakukan normalisasi ukuran, serta masking untuk menutup bagian sudut-sudut citra sehingga mengurangi variasi yang timbul pada bagian-bagian tersebut. Gambar 6 adalah contoh wajah yang berhasil dideteksi dan telah dilakukan histogram equalization, normalisasi ukuran dan masking.

\begin{tabular}{|c|c|c|c|}
\hline $\begin{array}{c}\text { Citra } \\
\text { Asli }\end{array}$ & $\begin{array}{c}\text { Hasil } \\
\text { Deteksi }\end{array}$ & $\begin{array}{c}\text { Citra } \\
\text { Asli }\end{array}$ & $\begin{array}{c}\text { Hasil } \\
\text { Deteksi }\end{array}$ \\
\hline$\Leftrightarrow$ & $6 \Rightarrow$ & & \\
\hline
\end{tabular}

Gambar 4. Hasil deteksi wajah 
Hasil deteksi wajah dengan latarbelakang yang terlalu bervariasi ternyata menghasilkan Region of Interest (ROI) wajah yang tidak bagus karena ada bagian wajah yang terpotong, atau masih terdapat bagian bukan wajah yang ikut ditampilkan, bahkan sampai tidak ditemukan wajah sama sekali.

\section{IV.III PEMBAHASAN KONSTRUKSI FISHERFACE}

Data wajah yang telah diperoleh dari hasil deteksi wajah, selanjutnya direpresentasikan ke dalam matriks. Pada citra JAFFE setelah dilakukan proses PCA, diambil 133 komponen dari matriks proyeksi PCA yang diperlukan untuk mengkonstruksi fisherface, dimana 133 merupakan selisih antara total citra latih dan banyaknya kelas ekspresi. Jadi dimensi dari ketiga tipe, masing-masing akan direduksi menjadi 133. Sedangkan pada citra dari database MUG diambil 497 komponen dari matriks proyeksi PCA yang diperlukan untuk mengkonstruksi fisherface. Jadi dimensinya direduksi menjadi 497.

Setelah dilakukan reduksi dimensi dengan perhitungan PCA, maka proses dilanjutkan dengan perhitungan LDA untuk mendapatkan matriks proyeksi fisher. Perhitungan LDA ini menghasilkan fisherspace berukuran $6 \times 140$ untuk citra JAFFE, dan $6 \times 630$ untuk citra MUG. Jadi setiap kolom adalah mewakili ciri ekspresi yang berbeda dari tiap orang.

\section{IV.IV PEMBAHASAN HASIL ARSITEKTUR JARINGAN SYARAF TIRUAN BACKPROPAGATION}

Arsitektur jaringan yang akan dikembangkan dalam penelitian ini terdiri atas 3 buah layer, yakni 1 buah input layer, 1 buah hidden layer dan 1 buah output layer. Jumlah neuron pada input layer adalah 6 neuron, hal ini sesuai dengan output dari proses konstruksi fisherface. Sedangkan jumlah neuron pada output layer adalah 7 neuron, sesuai dengan jumlah kelas ekspresi yang diteliti.

Parameter yang diberikan memiliki perubahan pada jumlah neuron hidden, dan nilai learning rate-nya. Pelatihan dilakukan sebanyak 6 kali dengan melakukan perubahan terhadap parameter jaringan syaraf tiruan. Parameter jumlah neuron hidden yang akan diujicoba adalah 12, 60, dan 120. Sedangkan untuk learning rate dipilih nilai 0,5 dan 0,25 . Target error akan diset dengan 0,0001 dan jumlah maksimum epoh adalah 1000 .

Jaringan syaraf tiruan yang optimal pada pengujian citra dari database JAFFE tipe I adalah dengan mengeset jumlah neuron hidden $=12$, dan learning rate $=0,5$. Pada citra tipe II, jumlah neuron hidden $=12$, dan learning rate $=$ 0,25 , dan pada citra tipe III, jumlah neuron hidden $=12$, dan learning rate $=0,25$. Sedangkan pada citra dari database MUG, jaringan syaraf tiruan optimal adalah untuk jumlah neuron hidden $=12$, dan learning rate $=$ 0,25 .

\section{IV.V Pengaruh UKuRAN Resolusi TerhadaP HASIL PENGENALAN}

Pada citra tipe I dengan ukuran $33 \times 29$ memberi hasil terbaik $86,85 \%$. Pada citra tipe II dengan ukuran $65 \times 57$ memberi persentase terbaik sebesar $89,20 \%$, sedangkan untuk citra tipe III dengan ukuran $130 \times 114$ mampu mengenali ekspresi sebesar $87,79 \%$. Jadi dapat dikatakan bahwa citra tipe II dengan ukuran $65 \times 57$ memberikan hasil yang lebih baik dibandingkan tipe I dan III.

\section{IV.VI HASIL PENGENALAN CITRA QUERY Pelatihan DAN NON - PElatihan DaRI DATABASE JAFFE}

Sistem pengenalan ekspresi wajah dari database JAFFE telah diuji menggunakan 213 citra di mana 140 citra telah dilatih (citra query pelatihan) dan 73 citra merupakan citra yang belum pernah dilatih sebelumnya (citra nonpelatihan). Data hasil pengenalan dengan hasil terbaik ditunjukkan pada tabel confusion matrix berikut ini. Hasil pengenalan terhadap citra query yang telah dilatih sebelumnya baik untuk citra tipe I, II, dan III memberikan hasil yang sama. Sistem mampu mengenali dengan baik seluruh citra yang dilatih sebelumnya. Tabel 3 merupakan confusion matrix hasil pengenalan pada citra query pelatihan baik tipe I, II, maupun III, sedangkan Tabel 4 sampai dengan Tabel 6 merupakan confusion matrix hasil pengenalan pada citra query non-pelatihan. 
Tabel 3. Confusion matrix untuk citra query pelatihan tipe I, II, dan III

\begin{tabular}{|l|r|r|r|r|r|r|r|}
\hline IlO & Netral & Marah & Senang & Sedih & Jijik & Takut & Terkejut \\
\hline Netral & $\mathbf{2 0}$ & 0 & 0 & 0 & 0 & 0 & 0 \\
\hline Marah & 0 & $\mathbf{2 0}$ & 0 & 0 & 0 & 0 & 0 \\
\hline Senang & 0 & 0 & $\mathbf{2 0}$ & 0 & 0 & 0 & 0 \\
\hline Sedih & 0 & 0 & 0 & $\mathbf{2 0}$ & 0 & 0 & 0 \\
\hline Jijik & 0 & 0 & 0 & 0 & $\mathbf{2 0}$ & 0 & 0 \\
\hline Takut & 0 & 0 & 0 & 0 & 0 & $\mathbf{2 0}$ & 0 \\
\hline Terkejut & 0 & 0 & 0 & 0 & 0 & 0 & $\mathbf{2 0}$ \\
\hline
\end{tabular}

Tabel 4. Confusion matrix untuk citra nonpelatihan tipe I

\begin{tabular}{|l|c|c|c|c|c|c|c|}
\hline I O & Netral & Marah & Senang & Sedih & Jijik & Takut & Terkejut \\
\hline Netral & $\mathbf{8}$ & 0 & 0 & 0 & 0 & 0 & 2 \\
\hline Marah & 1 & 6 & 0 & 0 & 0 & 0 & 2 \\
\hline Senang & 0 & 2 & 7 & 0 & 0 & 2 & 0 \\
\hline Sedih & 0 & 0 & 0 & $\mathbf{8}$ & 1 & 2 & 0 \\
\hline Jijik & 1 & 0 & 0 & 1 & $\mathbf{5}$ & 1 & 0 \\
\hline Takut & 0 & 1 & 0 & 2 & 1 & 7 & 0 \\
\hline Terkejut & 3 & 0 & 0 & 0 & 3 & 0 & $\mathbf{4}$ \\
\hline
\end{tabular}

Tabel 5. Confusion matrix untuk citra nonpelatihan tipe II

\begin{tabular}{|l|c|c|c|c|c|c|c|}
\hline IiO & Netral & Marah & Senang & Sedih & Jijik & Takut & Terkejut \\
\hline Netral & 9 & 0 & 0 & 0 & 0 & 0 & 1 \\
\hline Marah & 1 & 6 & 1 & 0 & 0 & 0 & 2 \\
\hline Senang & 0 & 2 & 7 & 1 & 0 & 0 & 0 \\
\hline Sedih & 0 & 0 & 0 & $\mathbf{8}$ & 0 & 1 & 0 \\
\hline Jijik & 0 & 0 & 0 & 0 & $\mathbf{5}$ & 1 & 0 \\
\hline Takut & 0 & 1 & 0 & 2 & 1 & 7 & 0 \\
\hline Terkejut & 0 & 0 & 1 & 0 & 0 & 0 & $\mathbf{8}$ \\
\hline
\end{tabular}

Tabel 6. Confusion matrix untuk citra nonpelatihan tipe III

\begin{tabular}{|l|c|c|c|c|c|c|c|}
\hline IlO & Netral & Marah & Senang & Sedih & Jijik & Takut & Terkejut \\
\hline Netral & 7 & 0 & 0 & 0 & 1 & 0 & 1 \\
\hline Marah & 2 & 3 & 0 & 0 & 0 & 0 & 0 \\
\hline Senang & 0 & 0 & 8 & 3 & 0 & 0 & 0 \\
\hline Sedih & 0 & 0 & 0 & 10 & 1 & 0 & 0 \\
\hline Jijik & 0 & 0 & 0 & 1 & 5 & 1 & 0 \\
\hline Takut & 0 & 1 & 0 & 1 & 0 & 7 & 1 \\
\hline Terkejut & 0 & 0 & 1 & 0 & 2 & 0 & 7 \\
\hline
\end{tabular}

\section{IV.VII PEMBAHASAN PENGENALAN CITRA QuerY PELATIHAN DAN NON-PELATIHAN DARI DATABASE MUG}

Hasil yang ditunjukkan pada Tabel 7 dapat dijelaskan bahwa sistem mampu mengenali semua ekspresi dari citra wajah yang telah dilatih sebelumnya. Hal ini dapat dilihat dari elemen diagonal utama pada confusion matrix yang merata dengan angka 72 , sedangkan elemen di luar diagonal utama sama dengan nol. Jadi tingkat pengenalan pada citra query pelatihan adalah $100 \%$. Hasil pengenalan pada citra query non-pelatihan ditunjukkan dengan confusion matrix pada Tabel 8.
Tabel 7. Confusion matrix untuk citra query pelatihan dari database $M U G$

\begin{tabular}{|l|c|c|c|c|c|c|c|}
\hline I0 & Netral & Marah & Senang & Sedih & Jijik & Takut & Terkejut \\
\hline Netral & $\mathbf{7 2}$ & 0 & 0 & 0 & 0 & 0 & 0 \\
\hline Marah & 0 & $\mathbf{7 2}$ & 0 & 0 & 0 & 0 & 0 \\
\hline Senang & 0 & 0 & $\mathbf{7 2}$ & 0 & 0 & 0 & 0 \\
\hline Sedih & 0 & 0 & 0 & $\mathbf{7 2}$ & 0 & 0 & 0 \\
\hline Jijik & 0 & 0 & 0 & 0 & $\mathbf{7 2}$ & 0 & 0 \\
\hline Takut & 0 & 0 & 0 & 0 & 0 & $\mathbf{7 2}$ & 0 \\
\hline Terkejut & 0 & 0 & 0 & 0 & 0 & 0 & $\mathbf{7 2}$ \\
\hline
\end{tabular}

Tabel 8. Confusion matrix untuk citra nonpelatihan dari database MUG

\begin{tabular}{|l|c|c|c|c|c|c|c|}
\hline IIO & Netral & Marah & Senang & Sedih & Jijik & Takut & Terkejut \\
\hline Netral & 17 & 0 & 1 & 0 & 0 & 0 & 0 \\
\hline Marah & 0 & 15 & 0 & 0 & 0 & 0 & 0 \\
\hline Senang & 0 & 1 & 17 & 0 & 0 & 0 & 0 \\
\hline Sedih & 0 & 0 & 0 & 16 & 0 & 0 & 1 \\
\hline Jijk & 0 & 0 & 0 & 0 & 18 & 0 & 0 \\
\hline Takut & 0 & 0 & 1 & 0 & 0 & 16 & 0 \\
\hline Terkejut & 0 & 0 & 0 & 1 & 0 & 0 & 15 \\
\hline
\end{tabular}

IV.VIII Perbandingan Hasil Pengenalan ANTARa Database JaFFe DAN Database MUG

Dari hasil pengujian yang telah dilakukan, didapatkan bahwa recognition rate untuk citra dari JAFFE adalah $86,85 \%$ (Tipe I), $89,20 \%$ (Tipe II) dan $87,79 \%$ (Tipe III). Sedangkan recognition rate pada citra MUG adalah 98,09\%. Dari nilai yang dihasilkan, tampak perbedaan nilai yang sangat signifikan dari kedua database tersebut. Di mana citra MUG cenderung dapat dikenali secara baik dengan ditunjukkan dari recognition rate yang tinggi (lihat Tabel 6.4).

Recognition rate yang tinggi ini salah satunya dipengaruhi oleh faktor akuisisi dari citra itu sendiri. Pada citra JAFFE, seorang expressor mengambil gambar ekspresinya sendiri sembari melihat melalui plastik semi reflektif yang berada di depan kamera. Setiap expressor berpose 3 sampai 4 contoh dari setiap ekspresi [6]. Sehingga dimungkinkan ada perubahan posisi dalam berpose. Pada citra dari database MUG merupakan citra sekuensial yang diambil menggunakan kamera yang mampu menangkap gambar rata-rata 19 frame per detik. Setiap sekuensial bisa terdiri 50 sampai dengan 160 citra. Dalam penelitian ini, citra yang digunakan dari database MUG hanya 5 yang diambil secara acak. Faktor sekuensial inilah yang mengakibatkan pose dari setiap expressor cenderung sama. 
Selain karena faktor akuisisi dari citra, banyaknya jumlah data yang digunakan untuk pelatihan juga berbeda. Pada citra JAFFE jumlah data yang dilatih ada sebanyak 140 buah citra dari 213 citra yang ada atau sebesar 65,57\%. Jumlah 140 buah citra ini diperoleh dari 2 citra $\times$ 7 ekspresi $\times 10$ subyek. Sedangkan pada citra MUG, jumlah citra yang dilatih ada sebanyak 504 buah citra dari 630 citra yang ada atau sebesar 80\%. Jumlah 504 buah citra ini diperoleh dari 4 citra $\times 7$ ekspresi $\times 18$ subyek. Dengan demikian semakin banyak jumlah citra yang dilatih semakin tinggi tingkat pengenalan ekspresinya.

Keseluruhan recognition rate yang diperoleh di atas juga sedikit berbeda dengan hasil pengujian yang dilakukan dengan menggunakan fungsi backpropagation (fungsi newff) yang build in matlab. Recognition rate terbaik untuk citra JAFFE tipe I dan II yang dihasilkan dengan menggunakan fungsi build in matlab adalah $89,20 \%$. Pada citra JAFFE tipe III, recognition rate terbaiknya adalah 92,02\%. Sedangkan pada citra MUG, recognition rate terbaiknya adalah $99,21 \%$. Perbedaan ini bisa diakibatkan karena ada perbedaan pembangkitan bobot antara fungsi yang dibuat, dengan fungsi yang build in matlab. Pembangkitan bobot pada fungsi yang dibuat adalah menggunakan prinsip inisialisasi Nguyen-Widrow. Penggunaan prinsip inisialisasi ini, bobot diskala menggunakan faktor skala, dengan sebelumnya dilakukan pembangkitan secara acak bobot dengan interval antara - 0,5 dan 0,5. Sedangkan bilangan acak yang dibangkitkan dari fungsi yang build in matlab secara default berada pada interval - 1 dan 1 .

\section{KESIMPULAN DAN SARAN}

\section{V.I KESIMPULAN}

Berdasarkan hasil analisis dan pembahasan yang telah dilakukan, dapat ditarik beberapa kesimpulan sebagai berikut:

1. Jaringan syaraf tiruan yang optimal pada pengujian citra dari database JAFFE tipe I adalah dengan mengeset jumlah neuron hidden $=12$, dan learning rate $=0,5$. Pada citra tipe II, jumlah neuron hidden $=12$, dan learning rate $=0,25$, dan pada citra tipe III, jumlah neuron hidden $=12$, dan learning rate $=0,25$. Sedangkan pada citra dari database MUG, jaringan syaraf tiruan optimal adalah untuk jumlah neuron hidden $=12$, dan learning rate $=0,25$.

2. Hasil pengenalan yang dilakukan pada citra database JAFFE maupun MUG memperoleh hasil sebagai berikut.

a. Citra JAFEE tipe I (ukuran $33 \times 29$ ) dengan recognition rate $=86,85 \%$, dan false positive $=25$.

b. Citra JAFFE tipe II (ukuran $65 \times 57$ ) dengan recognition rate $=89,20 \%$, dan false positive $=15$.

c. Citra JAFFE tipe III (ukuran $130 \times 114$ ) dengan recognition rate $=87,79 \%$, dan false positive $=16$.

d. Citra MUG (ukuran $65 \times 57$ ) dengan recognition rate $=98,09 \%$, dan false positive $=5$.

\section{V.II SARAN}

Berdasarkan pada pengujian yang telah dilakukan pada sistem yang dibuat, masih banyak kekurangan dan kelemahan sehingga perlu dikembangkan lagi agar kinerjanya lebih baik, oleh karena itu saran yang diberikan adalah sebagai berikut:

1. Peningkatan unjuk kerja sistem pengenalan ekspresi wajah, dapat dilakukan dengan memberikan pelatihan lebih lanjut dengan tambahan data training yang lebih banyak.

2. Deteksi wajah menggunakan integral projection, kurang baik untuk citra dengan latarbelakang yang sangat bervariasi. Pada kasus pendeteksian wajah di dalam citra berwarna dapat dikombinasikan dengan metode yang lain, misalnya dengan mendeteksi warna kulit terlebih dahulu baru dilakukan proses integral projection.

3. Dalam penelitian ini digunakan metode holistik dengan memanfaatkan ciri keseluruhan wajah, perlu dipertimbangkan untuk menambahkan ciri-ciri lokal wajah seperti alis, mata, mulut dan hidung untuk menambah akurasi kinerja sistem.

4. Antarmuka visual hendaknya dibuat lebih menarik dan memberi kemudahan dalam penggunaan sistem. 


\section{DAFTAR PUSTAKA}

[1] Bashyal, S., dan Venayagamoorthy, G.K., 2007, Recognition of Facial Expressions Using Gabor Wavelets and Learning Vector Quantization, Engineering Application of Artificial Intelligence. http://dx.doi.org/10.1016 /j.engappai.2007.11.010, 2007, diakses 2 Januari 2010.

[2] Delopoulos, A., The MUG Facial Expression Database, Multimedia Understanding Group, http://mug.ee.auth.gr/, diakses 5 Oktober 2010

[3] Deng, H.B., Jin, L.W., Zhen, L.X., dan Huang, J.C., 2005, A New Facial Expression Recognition Method Based On Local Gabor Filter Bank and PCA plus LDA, International Journal of Information Technology, 11, 11, $86-96$.

[4] Kulkarni, S.S., 2006, Facial Image Based Mood Recognition Using Committee Neural Networks, Thesis, Department of Biomedical Engineering University of Akron.
[5] Lekshmi V., P., dan Sasikumar, M., 2008, A Neural Network Based Facial Expression Analysis using Gabor Wavelets, World Academy of Science, Engineering and Technology, 42, $563-567$.

[6] Lyons, M., Akamatsu, S., Kamachi, M., dan Gyoba, J., 1998, Coding Facial Expression with Gabor Wavelet, Proceedings of The Third IEEE International Conference on Automatic Face and Gesture Recognition, 14 - 16 April 1998, 200 - 205.

[7] Ma, L. dan Khorasani, K., 2004, Facial Expression Recognition Using Constructive Feedforward Neural Network, IEEE Transactions on Systems, Man, and Cybernetics, 3, 34, 1588 - 1595.

[8] Yisu Z., Xiaojun S., Georganas, N.D., dan Petriu, E. M., 2009, Part-based PCA for Facial Feature Extraction and Classification, IEEE Transactions on Pattern Analysis and Machine Intelligence, 99 - 104. 